\title{
Game of Identities: A Study of Arya Stark and her Identities in Game of
} Thrones

\author{
Nasrin Begum
}

\begin{abstract}
"Game of Thrones" (2011-2019) is a hugely popular American tv series and Arya Stark is one of the protagonists of this series. This paper attempts to do a critical study on Arya Stark and a set of identities she undertakes voluntarily or involuntarily in her journey throughout the series. These identities are quite tricky and overlap each other. In many ways these identities confuse the audience as well as Arya herself. This paper will explore her quest for identities. It will also deal with her take on these set of identities as it is the very game of identities that define. affect, mould and transform Arya Stark in more than one ways . This paper will also try to examine the factors that contributed towards the formation of identities of the female protagonist.
\end{abstract}

Keywords: Identities, Trauma, Void, quest for Identity, Game.

\section{Introduction}

Game of Thrones, created by David Benioff and D.B. Weiss for HBO is actually based on A Song of Ice and Fire by George R.R. Martin. Game of Thrones is an international success and has a record number of viewership. The popularity of this series is not only for its twists and turns of the storyline but also for its brilliant characters. One of the most important characters is Arya Stark. The storyline centres on the seven kingdoms of Westeros and how they constantly fight and conspire, gamble and outshine each other for the ultimate throne. Arya Stark is the daughter of the noble Stark family of the North. She is the third child of Lord Eddard Stark and his wife Lady Catelyn Stark. Unlike her elder sister Sansa Stark who is homely, calm and quiet Arya is a non-conforming rebel. Since the very first episode, Arya is shown to be an important character and gradually throughout the onslaught of time, she turns out to be as one of the most powerful characters. Arya's journey is integral to the plot and a critic's eye finds very interesting elements in her character. Her character undergoes multiple layers of identities. She is in quest for identity, a true and authentic one. Sometimes she gets confused, sometimes she outdoes her previous identities even sometimes she retreats to her previous identities. Thus a study of Arya Stark and her identities posits quite an interesting study.

\section{Early Phase and the Formation of Identity}

The initial scenes of the series introduce Arya as someone different. She is not like the other girls of her age who enthusiastically responds to the grooming courses meant for wannabe 
ladies or wannabe wives of rich lords. While her elder sister Sansa Stark excels in sewing training given by Septa Mordane, Arya has her eyes fixed on his brothers who are busy practicing archery. Since the very first beginning Arya is keen on establishing her own identity. She does not conform to the stereotypical gender identities to which almost every girl of her times give in. It is interesting to remind that her elder sister is an expert in needlework but Arya excels in archery appreciating which her half-brother Snow gifts her a sword. Arya immediately names it as 'Needle'. This very word sets her apart from the stereotypes by giving her a unique identity. While girls use needle to excel in sewing work, Arya will use Needle to conquer and fight, protect and defend. Thus begins her new journey of formation of new identity.

Arya not only initiates the process of formation of identities, she does not forget to condition it. In Robert's court she learns sword fighting under the guidance of the master sword fighter Syrio. She clearly announces that she is not like someone who will beget Lords or Kings. She is not afraid to protest against anyone irrespective of their social status. She is brave and curious, confident and daring. She adds another unique perspective to her newly formed identity when her sword teacher teaches her to accept death as the only reality but eventually faces it with utmost courage and fighting spirit. Her whole world soon crushes down when she almost sees her father's execution in front of her eyes. She even draws her sword but soon grabbed by Yoren who rescues her from new king Joffrey and his mother Cercei's wrath. It is because of Yoren she gains another identity as he chops her hair and gives her a boy's identity so that she can get reunited with her half-brother Jon in the Night's Watch. This is another example of cross dressing but this new role gives her a powerful momentum.

Gradually she embarks on a new journey. This new journey even leads her to kill people. She even prepares a list of targets whom she wants to murder one by one. She helps a dangerous prisoner Jaqen H'ghar to escape but does not forget to take favours from him in the name of getting people killed by him. Though in the novels by Martin Arya is often presented as a ruthless girl, the HBO series does not fail to focus on her soft sides as well. She protects her obese friend Hot Pie's well being. Later on more than one occasions she tries to stop Hound from preying on innocent people. Arya is emotional but she does not let her emotions outsmart her mission. So, when Tywin asks her if she believes that Robb Stark can never be defeated, she denies so.

\section{Conflict and Tension between Identities}

Arya is constantly torn between two identities- one is of her new found free identity and another is her previous identity. So, when Jaqen offers her to go to Braavos, she declines it and decides to find her family first. She can be a rebel but not at the cost of her family. This strikes a comfortable equilibrium between her individual desires to attain freedom and her inherent sense of duty and care for her lost family. It is only after the Red Wedding episode (one where her mother, brother, pregnant sister-in-law are brutally killed and betrayed) we can find her to be strongly disillusioned about everything. She becomes indifferent to her personal securities as well. She finally decides to embark on a journey to the city of Braavos. Her stay in this city of Braavos is very significant on many levels. Before that let us quickly remind us ourselves what actually happened in the city of Braavos. Arya meets Jaqen who tries to teach her how to become a faceless being. Arya constantly stumbles in the process of becoming a facesless identity as very often she vividly discloses her own identity of being Arya Stark. Even when she accomplishes the task of being a faceless one, she leaves the place after vehemently tellingJaqen that she will always think of herself as Arya Stark of Winterfell. It is very interesting to observe that Arya could pick up as many identities as she wished in Braavos but she finally chooses her old identity which is nothing but the natural and genetic continuation of her ancestors., Thus unknowingly she retreats in the game of identities. She recedes to her previous identity but this time she avenges her mother's and 
brother's death by killing Lothar Frey, Walder Rivers, Walder Frey that too with the help of the face masks collected from the faceless man Jaqen. She went to the Twins but this time not in her actual identity of a noble Arya Stark. She went there in the disguise of a servant girl. There was a celebration being conducted by the Freys with the Lannisters for a success in the warfront. Arya murdered her victims and then cooked their meat into pies. She even served the meat to Walder Frey. The episode took a dramatic turn when Walder Frey found a human part in his food, Arya went bolder and revealed her true identity of being Arya Stark. This time she killed him and after giving him a gory death she then opted for Walder Frey's face. Soon after when the rest of the men of the house of Frey died, Arya again put off the mask of Walder Frey which she was wearing upto that time. She did not forget to inform Walder's last wife that the North remembers and Winter came for House Frey. This episode threw another interesting light on the identity games of Arya Stark that she chose quite pragmatically. She disguised her identity when the situation demanded. She knew that a Stark is not at all welcome in an enemy house of Frey. Thus she is a practical one and so prioritizes her life over any other thing in the world. She does not forget to reveal her true identity twice when her revenge is executed. Here she reveals her identity when she considers her circumstances to be safe and secure enough. Thus here her two identities cross and intermingle, affect and assist each other. When she learns that her half -brother Snow has recaptured Winterfell from the traitors, Arya cancels her plan of going to King's Landing and decides to join her family back at Winterfell. Thus the Braavos episode throws a new light on Arya Stark and her quest for identity. As Arya always wanted to go beyond the stereotypical roles that the society assigns to a woman or even a girl, she always wanted to choose the less explored avenues. But it was for her unending love for her family that she somehow mellowed herself out a bit. When she found out that her mother, brother and sister-in-law were brutally murdered, she filled a void in herself. This very void led her to choose the path of faceless identity. This is symbolic of the void she faces in a world which is bereft of her parents and brothers. Though she almost succeeded in becoming a nameless, faceless identity she could not tolerate this rootlessness and fragmentation for a prolonged amount of time. So, she again switched back to her inherited identity of a Stark family.

\section{Towards the End: Identities and Responsibilities}

Arya returns to Winterfell and reunites with her elder sister Sansa and brother Bran and later with her half -brother Jon Snow. The final two seasons of this series almost transformed Arya from a lonely fighter into a saviour of the Seven Kingdoms. A tension develops between two sisters as Littlefinger deliberately creates confusion between them by making Arya read a letter written by Sansa long ago under the pressure of Cersei. Since the very beginning Arya's brave identity collided with the submissive identity of Sansa. It led to the initial disliking between two sisters. A brave Arya snapped at Sansa's previous surrender to the Lannisters. Littlefinger however fails to make them apart and soon his own lies and schemes get exposed. Arya kills Littlefinger on her elder sister's orders. They finally have a union.

Soon Jon Snow arrives to Winterfell with Queen Daenerys Targaryen and her gigantic dragons. Soon more houses join in to fight the Army of the Dead which is considered the greatest threat for all the people of the Seven Kingdoms by Jon Snow. Arya meets Gendry, her old companion at Harrenhal. All the life Arya was fleeing from the typical feminine traits which even includes any attraction for a male but in the night of the probable attack by the Army of the Dead, she initiates physical intimacy with Gendry. She dons here a new identity which was hitherto not seen within her. It is not altogether a lovesick identity of a teenager but an extension of another interesting facet of her earlier adventurous identity. She participates in love making just because of the apprehension of the impending death. She wants to savour the pleasure of physical intimacy just before her death. Gendry starts sleeping after their intimacy but Arya is not at all emotionally overwhelmed as she lies pretty 
awake to resume her duty of protecting people against the Dead. Her emotional detachment is clearly visible after the win in the battle too when Gendry proposes her to be his Lady. Arya declines the offer indicating that it is unlikely of her to become a Lady. Thus Arya surprises the audience with the newer facets of her personality. She confidently precedes through a multiple identities or rather say multiple facets of her identity. It is her efficiency and swiftness that creates a halo of unpredictability around her so that we get puzzled and surprised at the multiple layers of her identity.

The battle with the White Walkers also symbolizes another interesting perspective of Arya Stark. Since the very beginning of the series, it was Jon Snow who first felt the importance of fighting against the White Walkers. Snow sacrificed many things even his mortal security once to assemble so many people of different opinions to bring them together to fight the battle between the Living and the Dead. He almost arranged a miraculous assemblage of people from different Houses so it was normally expected from the point of view of the audience that Snow would put on the role of a saviour. Interestingly enough, irrespective of the multiple war strategies and prowess Snow fails. While a valiant Snow gets busy to fight a ghost of a dragon, Arya reaches to the godswood only to find that the Night King is approaching fast to kill her little brother Bran. Arya attacks the Night King from behind and finally kills him with her dagger made up with Valyrian steel. Thus Arya sets herself apart from many women of her times by not only displaying a great amount of bravery but also single handedly killing the unconquerable Night King. She braves the journey from being a novice sword fighter to the saviour of her people. She rescues her physically crippled brother and saves a whole race.

In the final episode of Season 8, when Bran exiles Jon to the Watch after his killing of Daenerys, Arya informs her siblings that she has decided to sail to the west of Westeros. She gives Jon an emotional farewell and on being questioned informs him that she still carries Needle with her. She still carries Needle, a prominent symbol of her previous identity. She later sails on a ship with the Stark logo and explores her journey into the unknown.

\section{Arya's Quest for Identity and the Traits That Set Her Apart From Others}

Thus Arya leaves all the comfort and even a marriage proposal from a man who loves her dearly and she embarks on a journey. This time her journey is not originated from any compulsion or fear from her enemies. It is her spontaneous decision, a decision which ultimately sets her personality apart from other characters as well. While Jon retreats to the Watch more out of his remorse for killing his own love, Sansa joyfully goes back to her home to become the queen in the North, Bran ascends the throne, it is Arya who acted on her own will. Hers is neither a compulsion nor regret. Thus in the end she fully succumbed to her own desires of exploring new unknown lands. She also contrasts herself with three major female characters of this series- Cercei, Sansa and Daenerys. Both Cercei and Daenerys displayed very strong personalities but both of them even compromised their modesty in order to form allies. Thus their identities could not outsmart the temptation of the throne. It is for the temptation, both of them caused many innocent deaths which also resulted directly or indirectly towards their own deaths. Sansa, on the other hand is not such cruel and violent but her love for the power also led to many unfortunate incidents even her distance from Snow and Arya. Thus throughout the journey of the series, Arya strikes a unique note as she kills the cruel ones, rescues the helpless ones and to top it all she simultaneously preserves a unique identity of her own.

\section{Arya's Identities- A Critical Summing Up}

It is a debatable topic to decide which one is Arya's original identity? Is she a naïve swordfighter? A clever young girl? An incredibly superpower or a little timid girl putting on a face of a braveheart. Many will have different opinions. Actually Arya was born different. It is for 
her love for her father she wanted to be a fighter, not merely a lady waiting to be married off to a rich lord. In this way she rises not only above the gender roles but also above the notions of nobility, class and social status. That is why Arya treated his bastard half-brother Jon Snow more kindly than her own mother. She never boasted of her social status to anyone. She never exploited her own family status to gain anything under the sun. She is a natural charmer. She has a lifelong quest for her own identity. Sometimes she forms her own identity, soon enough her circumstances leads her to choose different path altogether and in this process a new perspective of her identity gets added to her personality. Her continuous search for an integrated identity defines her journey. Arya, like Joseph in Saul Bellow's Dangling Man continues to dangle between two selves. Arya suffers from a continuous dangling between two identities- one of a fighter and one of a Stark. These two identities affect her, mould her and transform her into a complete whole. Ultimately after performing all the duties as a Stark daughter only, she starts for a new journey on sea. Herein lies the perfect balance of her character. She is enthusiastic about forming her own identity but she never puts it first. To her family comes first. She neither forgets her roots nor her wings. She dares to fly but does not forget to remember those who are on the ground waiting to be found and rescued. Herein lays her greatness and strength. She is not an escapist. Whereas her elder sister Sansa puts her dreams of becoming a queen over her family in the initial episodes of the series, Arya is a devoted follower of her family. She did not even think twice before drawing out her sword to defend her father while Sansa remained as a passive presence in the audience. She did not care for her life even amidst the innumerable presence of the White Walkers but paved her way to rescue her crippled brother. Arya Stark is not only a brave, independent woman but also a noble soul who believed in miracles, love and truth. Hers is a tragic life throughout which she searches for her true identity. The journey is not smooth but a rough and patchy one in which she loses her parents, her brothers. She bleeds but heals herself and starts a new journey to face new wounds and new methods of healing herself.

Arya Stark successfully indulges into a game of identities. Her inborn brave and rebel nature initiates this game but soon enough circumstances led her to gather wounds and traumas. It is because of this onslaught of traumas and void she somehow gets forced to opt for a new identity or another. But luckily or unluckily all her new identities satisfied her hidden desires to be someone above than the average. She was indeed a square peg in a round hole and it was because of this she could not fit in a patriarchal set up that a society has to offer to a woman or even to a girl. That is why her identities allowed her to explore strikingly different avenues which somehow catered to her kaleidoscopic interests. She got thrilled like a girl, shed blood like a blood thirsty murderer who had the names ready for her future victims. But even if she killed, she killed those who were monsters in their own way or the other. She never killed anyone merely for blood thirst. She even spared Hound although he pleaded her to kill him. Thus Arya never got derailed from the values that his kind parents taught her in childhood. Somehow the void created by the death of her parents gave her a new and integrated identity which bridged all her previous quest for identities. This gave power to her, healed her, and stitched up all her fragmented parts in a definite yet simple, organic yet thrilling way. Therefore Arya Stark is indeed a winner in her game of identities. Though she never reaches any conclusion in her quest but then life itself is a continuous quest for achieving new identities. The quest must go on to find out the unknown avenues. Therefore it can be concluded that Arya's journey from one identity to another is basically prompted by her psychological journeys from one part of her self to another part.

\section{References}

Beauvoir, S. D. (1997). The second sex. Random House.

Bellow, S. (2013). Dangling man. Penguin UK.

HBO Entertainment; co-executive producers, George R.R. Martin, Vince Gerardis, Ralph 
Vicinanza, Guymon Casady, Carolyn Strauss; producers, Mark Huffam, Frank Doelger; executive producers David Benioff, D.B. Weiss; created by David Benioff \& D.B. Weiss; Television 360; Grok! Television; Generator Entertainment; Bighead Littlehead. (2012). Game of thrones. The complete first season. HBO Home Entertainment.

Martin, G. R. (1998). A clash of kings. HarperCollins UK.

Martin, G. R. (2003). A storm of swords: A song of ice and fire: Book three. Bantam.

Martin, G. R. (2005). A feast for crows: A song of ice and fire: Book four. Bantam.

Martin, G. R. (2010). A game of thrones (A song of ice and fire, book 1). HarperCollins UK.

Martin, G. R. (2011). A dance with dragons: A song of ice and fire: Book five.

\section{$\underline{\text { Bio-note }}$}

Nasrin Begum is a Research Scholar of The University of Burdwan. Her Broad Research area is American literature. Her Areas of Academic Interest include Culture Studies, Diaspora etc.

E-mail: nbscholar.1988@outlook.com

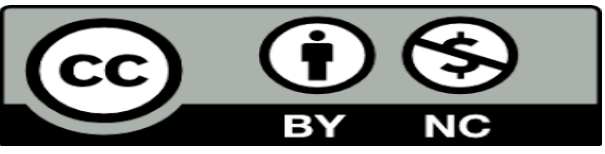

